\title{
Rotosphaeropsis thula (Davey 1982) comb. nov., emend.: a dinoflagellate cyst from the Upper Jurassic-Lower Cretaceous of England
}

\author{
James B. Riding' \& Roger J. Davey ${ }^{2}$ \\ ${ }^{1}$ British Geological Survey, Keyworth, Nottingham NG12 5 GG. \\ ${ }^{2}$ The Robertson Group plc, Llandudno, Gwynedd LL30 1SA.
}

\begin{abstract}
The Upper Jurassic-Lower Cretaceous dinoflagellate cyst Cannosphaeropsis thula Davey 1982 does not conform to the morphological parameters of the genus Cannosphaeropsis O. Wetzel 1933 emend. Duxbury 1980. The species also exhibits no indications of belonging to the Spiniferites complex of Evitt (1985). The species is transferred to Rotosphaeropsis Davey 1987 by virtue of its shape, archaeopyle type, processes and trabeculae and the specific diagnosis is emended in the light of this reassessment.
\end{abstract}

\section{INTRODUCTION}

During the course of separate palynological investigations into the Upper Jurassic and Lower Cretaceous strata of eastern England, both authors encountered large numbers of the dinoflagellate cyst Cannosphaeropsis thula Davey 1982. This species was previously placed in open nomenclature, as Cannosphaeropsis sp. A Davey 1979, and is of stratigraphical significance, ranging from the Upper Kimmeridgian (sensu anglico) to the Upper Ryazanian in north-west Europe (Davey, 1979; Duxbury, 1977, 1978; Riding, 1984).

The morphology of this taxon does not accord with that of the genus Cannosphaeropsis O. Wetzel 1933 emend. Duxbury 1980, principally because the paratabulation of $C$. thula differs markedly from that of Spiniferites Mantell 1850 emend. Sarjeant 1970 and also it lacks processes of Spiniferites-type. Cannosphaeropsis is a member of the Spiniferites complex within the informal category of Gs-cysts of Evitt (1985). The Spiniferites complex contains genera with widely differing morphologies, yet a distinctive series of constant features which strongly suggest a close biological relationship. The most important of these features are: trifurcate gonal and bifurcate intergonal processes (the primary furcations pointing to the centres of adjacent paraplates); a strongly sigmoidal (S-type of Evitt, 1985) parasulcus lacking intraparasulcal parasutures and normally, a single paraplate precingular archaeopyle (see Evitt, 1985 fig. 5.8B). Cannosphaeropsis thula Davey 1982, while sharing certain morphological features with Cannosphaeropsis, has a longitudinal parasulcus (Ltype of Evitt, 1985 - see Figure 1 and Plate 1, fig. 1) and lacks Spiniferites-type processes. The purpose of this short communication is to transfer $C$. thula to Rotosphaeropsis Davey 1987, which is consistent with the morphology of this species, and to make certain minor emendations to the specific diagnosis.

\author{
SYSTEMATIC SECTION \\ Division Pyrrhophyta Pascher 1914 \\ Class Dinophyceae Fritsch 1929 \\ Order Peridiniales Haeckel 1894
}

Genus Rotosphaeropsis Davey 1987

Type species: Rotosphaeropsis munu Davey 1987

Rotosphaeropsis thula (Davey 1982) comb. nov.,
emend. nov.

(Pl. 1, figs. 1-9; Figure 1)

1977 Adnatosphaeridium apiculatum auct. non (Cookson \& Eisenack 1960) Lentin \& Williams 1973; Duxbury: 23, pl. 10, fig. 1.

1978 Adnatosphaeridium apiculatum (Cookson \& Eisenack 1960) Lentin \& Williams 1973 sensu Duxbury $1977=$ Cannosphaeropsis sp. A of Davey (in press); Duxbury: pl. 1, figs. 6, 7.

1979 Cannosphaeropsis sp. A Davey: 56, pl. 1, figs. 6 , 9, 12.

1982 Cannosphaeropsis thula Davey: 26, pl. 8, figs. 7-11.

Emended diagnosis. A species of Rotosphaeropsis, ovoidal in overall shape with little, if any, dorso-ventral flattening. Cyst apparently two-layered, the two layers being closely appressed except where the periphragm alone forms the processes; cyst wall smooth to scabrate. Cyst body covered by numerous, slender, solid, parasutural processes at both gonal and intergonal positions. The processes are variable in length, from $12 \%$ to $73 \%$ of the cyst body width; they are generally longest on the hypocyst and shorter on the epicyst. The majority of the processes flare distally where they are consistently interconnected by parasutural trabeculae. The elements of the trabeculae are normally similar in 


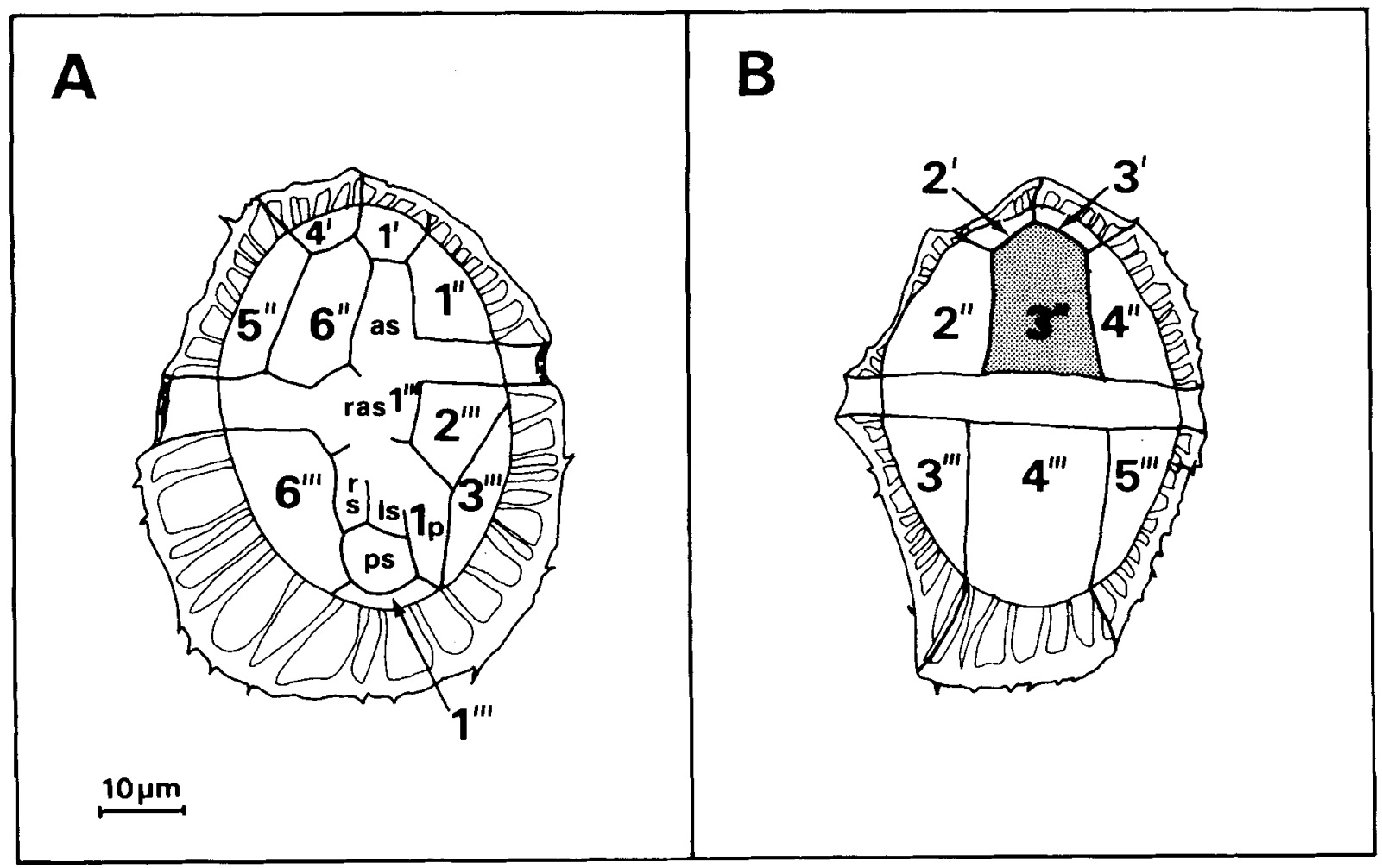

Fig. 1. Line drawing of an idealised specimen of Rotosphaeropsis thula (Davey 1982) comb. nov., emend. Paraplates labelled utilising Kofoidian notation. A - ventral surface. B - dorsal surface (note the archaeopyle has operated).

\section{Explanation of Plate 1}

Magnification, all figures $\times 500$. All figured material is housed in the micropalaeontological collections of the Biostratigraphy Research Group, British Geological Survey, Keyworth, Nottingham.

Figs. 1-10. Rotosphaeropsis thula (Davey 1982) comb. nov., emend. nov.

All specimens from the Lower Spilsby Sandstone, Beds 3 or 5 of Casey, 1973 (Subcraspedites primitivus Zone), Portlandian of Nettleton Top Barn, south-west of Caistor, Lincolnshire (TF 1072 9932), unless otherwise stated.

Figs. 1-3. Specimen MPK 4802. Bed No. 5. Ventral view, ventral to dorsal focus sequence. Note the longitudinal (L-type) parasulcus, well-defined paratabulation indicated by trabeculae (1) and the single paraplate precingular archaeopyle (3).

Fig. 4. MPK 2618. The holotype, dorsal view, ventral focus. Sandringham Sands (H. kochi Zone), Lower Ryazanian of a channel west of Abbey Station Bridge, Norfolk (TL 660 996).

Fig. 5. MPK 4804. Bed No. 3. Dorsal view and focus.

Fig. 6. MPK 4805. Bed No. 5. Dorsal view and focus. Note the prominent, type $P\left(3^{\prime \prime}\right)$, archaeopyle which appears to be slightly enlarged posteriorly.

Fig. 7. MPK 5105. Bed No. 3. Dorsal view and focus.

Fig. 8. MPK 4807. Bed No. 5. Oblique ventral view and focus.

Figs. 9, 10. MPK 5106. Right lateral view: 9, high focus; 10, low focus. Note archaeopyle (upper left) and relatively long processes in the ventral area (right). Lower Spilsby Sandstone, Bed 2 of Casey, 1973 (Paracraspedites oppressus Zone), Portlandian of Fordington No. 1 borehole, north of Spilsby, Lincolnshire (TF 416 714).

Fig. 11. Cannosphaeropsis utinensis O. Wetzel 1933 emend. Duxbury 1980.

MPK 5107. Figured for comparative purposes (See also Evitt, 1985 Figs. 5.8B, 5.12E-H, J, 10.7); note the prominent trabeculum which exhibits trifurcate gonal and bifurcate intergonal processes which surmount the trabeculae. Each ray of these features, which are characteristic of the Spiniferites complex of Evitt (1985), points to the centre of the adjacent paraplate and is bifurcate distally.

Paramoudra Chalk (Upper Chalk) - Belemnitella mucronata Zone - Upper Campanian of the Trunch borehole, Norfolk (TG 2933 3455). 

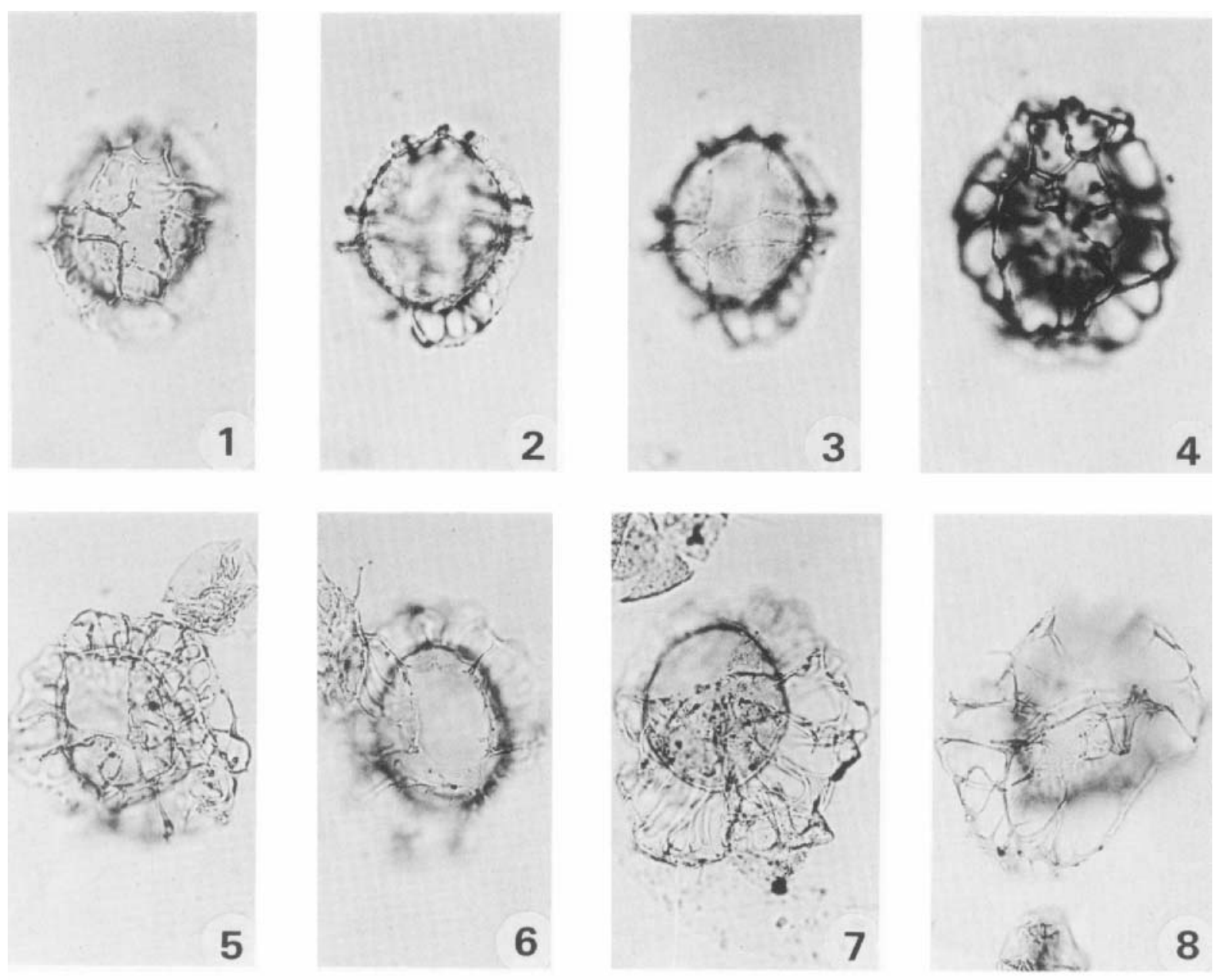

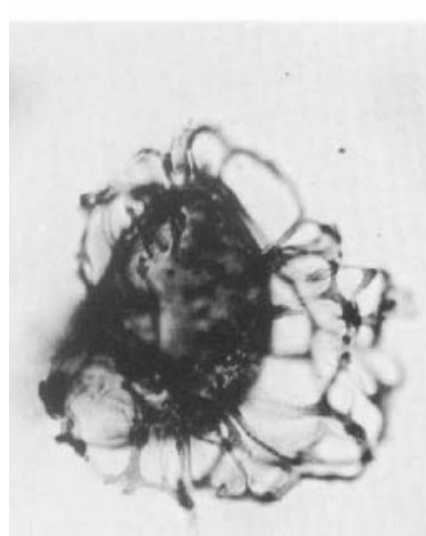

9

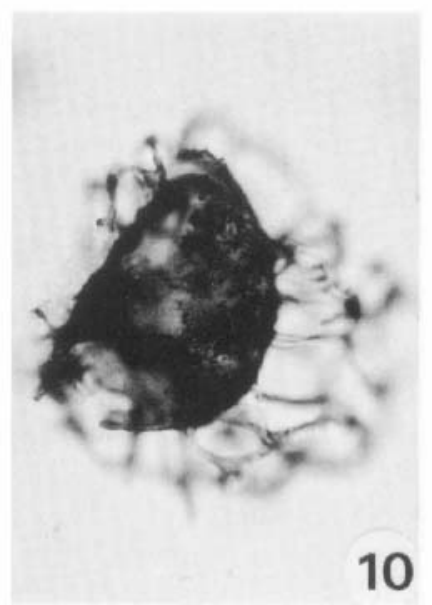

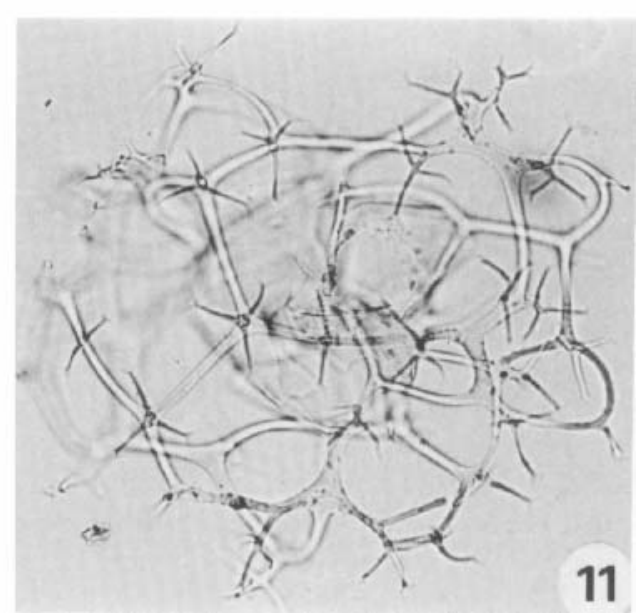


width to the processes, but may broaden markedly and bear distally low, irregularly-spaced spines or denticles. Paratabulation sexiform gonyaulacacean, indicated by trabeculae, Kofoidian formula: 4', 6", ?6c, 6"', 1p, $1^{\prime \prime \prime \prime}$, 5s. Paracingular and parasulcal trabeculae are rarely discernible and the former may be partially suppressed. Parasulcus longitudinal (L-type of Evitt, 1985). Archaeopyle precingular, type P $\left(3^{\prime \prime}\right)$, operculum free. Size, small to intermediate.

Holotype. Specimen MPK 2618, BGS slide SAL 5260/4. Sandringham Sands, Hectoroceras kochi Zone, Lower Ryazanian. Cut off channel, 600-700m west of Abbey Station Bridge, Norfolk, England (TL 660 996).

Dimensions. Overall cyst length: $48-84 \mu \mathrm{m}$. Overall cyst width: $38-72 \mu \mathrm{m}$. Process length: $9-28 \mu \mathrm{m}$.

Remarks. This species has been transferred to Rotosphaeropsis Davey 1987 as it exhibits distal trabeculae surmounting irregularly-spaced parasutural processes, a precingular archaeopyle and lacks Spiniferites-type processes. The basionym genus, Cannosphaeropsis, although superficially similar in terms of basic cyst organisation, shape and archaeopyle type, is inappropriate as it differs markedly in crucial details of paratabulation and morphology. $R$. thula comb. nov., emend. nov. has a longitudinal parasulcus; Cannosphaeropsis, by virtue of its position within the Spiniferites complex, has a sigmoidal ventral area. Certain topological paratabulation differences associated with L-type and S-type parasulci therefore exist between $R$. thula and Cannosphaeropsis, for example the former has a subparallel sided $6^{\prime \prime}$ paraplate whereas the equivalent in the latter is pseudotriangular (see Evitt, 1985 fig. 5.8B). In addition, $R$. thula exhibits intraparasulcal trabeculae (Pl. 1, fig. 1), features not associated with Spiniferites and its allies. Rotosphaeropsis thula lacks the characteristic (of Cannosphaeropsis) triradiate branches at gonal points and the paired branches located intergonally on the trabeculae (see Plate 1, fig. 10). Cannosphaeropsis exhibits a much reduced number of gonal processes and entirely lacks intergonal shafts, a situation differing markedly with the full complement of gonal processes together with the numerous intergonals of $R$. thula. The distally flared processes and thickened trabeculae of $R$. thula are unknown in Cannosphaeropsis.

The processes of $R$. thula are very variable in length. The paratabulation is readily discernible in forms with low parasutural processes although morphotypes with longer shafts tend to be distorted making the paratabulation difficult to interpret. Davey (1982) commented that the number of processes is greater in specimens from the Upper Kimmeridgian to lowermost Portlandian.

Rotosphaeropsis thula differs from $R$. munu, the type species, in that the cyst body of the former is less elongate; $R$. munu has considerably more numerous processes, which are consistently longer than those of $R$. thula. Medial/distal cross linkage of processes, in addition to the trabeculae, are characteristic of $R$. munu but are not exhibited by $R$. thula. Because of the relatively long and complex processes of $R$. munu, the trabeculae are invariably distorted and the detailed paratabulation cannot be established.

Stratigraphical Distribution and Geographical Occurrence. The total range of $R$. thula onshore is Upper Kimmeridgian (sensu anglico), Pectinatites hudlestoni Zone to Upper Ryazanian, Surites stenomphalus Zone; it is most common (up to $5 \%$ of the dinoflagellate cyst assemblage) from the Portlandian, Galbanites kerberus Zone to the Lower Ryazanian, H. kochi Zone. $R$. thula has been reported from England and Denmark and occurs extensively in the North Sea Basin (personal observations).

\section{ACKNOWLEDGEMENTS}

J. B. Riding and R. J. Davey publish with the approval of the Director, British Geological Survey (NERC) and the Directors of the Robertson Group plc respectively.

\section{Manuscript received May 1988 \\ Revised manuscript accepted March 1989}

\section{REFERENCES}

Casey, R. 1973. The ammonite succession at the JurassicCretaceous boundary in eastern England. In Casey, R. \& Rawson, P. F. (Eds.): The Boreal Lower Cretaceous, Geological Journal Special Issue No. 5, 193-266. Liverpool.

Davey, R. J. 1979. The stratigraphic distribution of dinocysts in the Portlandian (latest Jurassic) to Barremian (Early Cretaceous) of north-west Europe. American Association of Stratigraphic Palynologists Contributions Series, No. 5B, 49-81. Dallas.

Davey, R. J. 1982. Dinocyst stratigraphy of the latest Jurassic to Early Cretaceous of the Haldager No. 1 borehole, Denmark. Danmarks Geologiske Undersøgelse, Serie B, Nr. 6, 57p. Copenhagen.

Davey, R. J. 1987. Palynological zonation of the Lower Cretaceous, Upper and uppermost Middle Jurassic in the north-western Papuan Basin of Papua New Guinea. Geological Survey of Papua New Guinea, Memoir 13, 77p.

Duxbury, S. 1977. A palynostratigraphy of the Berriasian to Barremian of the Speeton Clay of Speeton, England. Palaeontographica Abt. B 160, 17-67. Stuttgart.

Duxbury, S. 1978. Early Cretaceous dinoflagellate cysts. In Thusu, B. (Ed.) Distribution of biostratigraphically diagnostic dinoflagellate cysts and miospores from the North-west European continental shelf and adjacent areas, 19-29. Continental Shelf Institute Publication, 100. Trondheim.

Evitt, W. R. 1985. Sporopollenin dinoflagellate cysts. Their morphology and interpretation. American Association of Stratigraphic Palynologists Foundation, 333p. Dallas.

Riding, J. B. 1984. Dinoflagellate cyst range-top biostratigraphy of the uppermost Triassic to lowermost Cretaceous of North-west Europe. Palynology, 8, 195-120. Dallas. 